\title{
SAMPLING SUARA INSTRUMEN MUSIK SEBAGAI STRATEGI PENINGKATAN HASIL BELAJAR MAHASISWA DALAM PEMBUATAN FILM SCORING
}

\author{
Pandan Pareanom Purwacandra \\ Program Studi D-3 Animasi, Fakultas Seni Media Rekam \\ Institut Seni Indonesia Yogyakarta \\ Jalan Parangtritis Km 6,5 Sewon, Bantul, Yogyakarta \\ No. Hp.: 081804378383,E-mail: pandanharmony@gmail.com \\ Oriana Tio Parahita Nainggolan \\ Program Studi S-1 Pendidikan Musik, Fakultas Seni Pertunjukan \\ Institut Seni Indonesia Yogyakarta \\ Jalan Parangtritis Km 6,5 Sewon, Bantul, Yogyakarta \\ No. Hp.: 08132800 8082, E-mail: orianatioparahitangl@gmail.com
}

\begin{abstract}
ABSTRAK
Film scoring merupakan pembuatan musik untuk mengiringi gambar visual dalam film. Dalam pembuatan film scoring sangat dibutuhkan pengetahuan tentang musik karena film scoring memiliki tujuan untuk menciptakan emosi penonton agar dapat memahami film yang ditonton. Instrumen musik merupakan elemen musikal yang mendukung terciptanya emosi penonton. Penelitian ini memiliki tujuan meningkatkan hasil belajar mahasiswa Program Studi D-3 Animasi, Fakultas Seni Media Rekam, Institut Seni Indonesia Yogyakarta dalam pembuatan film scoring dengan strategi pembelajaran menggunakan sampling suara instrumen musik. Untuk mengetahui peningkatan hasil belajar mahasiswa, digunakan penelitian tindak kelas dengan tiga siklus. Indikator keberhasilan hasil belajar mahasiswa didapat dari nilai dalam tugas membuat film scoring. Hasil penelitian menunjukkan bahwa terjadi peningkatan hasil belajar mahasiswa pada akhir siklus ketiga dari PTK dengan menggunakan strategi pembelajaran sampling suara instrumen musik. Hasil belajar mahasiswa ini ditunjukkan dengan jumlah mahasiswa yang mendapat nilai amat baik dan baik, yaitu sekitar 93,75\% (15 dari 16 mahasiswa. Berdasarkan hasil tersebut, dapat disimpulkan bahwa penggunaan strategi sampling suara instrumen musik meningkatkan hasil belajar mahasiswa dalam pembuatan film scoring.
\end{abstract}

Kata kunci: sampling suara instrumen, film scoring, film musik

\section{ABSTRACT}

Sampling of Musical Instrument as a Strategy of Improving the Students' Learning Outcome in Making Film Scoring. Film scoring is a music written specifically to accompany a movie. The knowledge about music plays an important role in the making of film scoring, because a film scoring has the purpose to evoke audience's emotion so they will understand the film message. Musical instrument is a musical element that creates audience's emotion while watching film. This research aims to enhance students'learning outcomes at Animation Study Program, Faculty of Recorded Media Arts, Indonesia Institute of the Arts Yogyakarta in making film scoring by using sampling musical instrument as the learning strategy. This research is a classroom action research with three cycles. The indicator of students'learning outcomes is gathered from number of students who got excellent grade in making film scoring. The results shows that there is an improvement in the students'learning outcomes by the end of the third cycle from PTK by using the strategy of sampling of musical instrument. From 16 students the outcome shows that around 93,7\% (15 out of 16) of the students get either good 
or excellent results. Based on that result, the conclusion that can be drawn is that the sampling strategy of musical instrument improves students' learning outcome in making film scoring.

Keywords: sampling of musical instrument, film scoring, film music

\section{PENDAHULUAN}

Film scoring (movie scoring, film music, atau background music) merupakan musik yang dibuat untuk mengiringi adegan dalam film (Indovoiceover, 2016). Film scoring dibuat untuk menciptakan emosi penonton. Film scoring dibuat untuk menguatkan dan mempertegas emosi dalam adegan tertentu. Cohen menjelaskan bahwa film scoring juga berfungsi untuk menjaga kesinambungan antarpotongan-potongan video untuk membentuk satu kesatuan cerita dan ide (Cohen, 2001).

Musik merupakan elemen penting dalam pembuatan film scoring. Dalam film, dialog dan akting merepresentasikan apa yang sedang dilakukan dan dipikirkan oleh pemain film, sedangkan musik merepresentasikan apa yang dirasakan oleh pemain film terhadap dialog dan akting mereka (Douek, 2013), dalam hal ini musik memunculkan persepsi ekspresi emosi (Nalan, 2017). Musik tidak saja memengaruhi pemain film, tetapi juga emosi penonton sehingga muncul keterlibatan emosional antara pemain dan penonton (Kurniawan, 2016).

Melihat pentingya fungsi musik dalam sebuah film, dibutuhkan pengetahuan akan musik dalam pembuatan film, terutama dalam pembuatan film scoring. Dalam pembuatan film scoring, pengetahuan tentang musik yang harus diketahui adalah instrumen musik. Instrumen musik dapat mempengaruhi emosi seseorang (Wu, Horner, \& Lee, 2014)"type":"paperconference" \},"uris":[“http://www.mendeley. com/documents/?uuid=5196ae12-59fc-44d7- 913d-45041670903d","http://www.mendeley. com/documents/?uuid=55dd8f80-919e-4f3a9c61-62a5547241c9"]\}],"mendeley": \{“for mattedCitation":"(Wu, Horner, \& Lee, 2014. Instrumen musik dapat menciptakan suasana, nuansa, mood dari film, serta mempertegas emosi dari sebuah film. Setiap instrumen musik memiliki karakteristik suara yang unik sehingga pengetahuan terhadap masing-masing instrumen musik harus dimiliki oleh pembuat film scoring. Pembuatan film scoring juga disesuaikan berbagai macam karateristik film. Karakteristik film scoring dibuat berdasarkan genre (tema) film (Mark, 2003). Karateristik film scoring dipengaruhi oleh elemen-elemen musik seperti penggunaan tangga nada (modus), harmoni, dinamika, pemilihan penggunaan instrumen musik, dan elemen musik lainnya.

Pemilihan instrumen musik yang hendak digunakan dalam pembuatan film scoring menjadi sebuah hal yang penting karena setiap instrumen musik memiliki karakteristik suara tertentu. Tidak semua instrumen musik dapat digunakan dalam sebuah film sehingga pemilihan instrumen musik dalam pembuatan film scoring menjadi hal yang utama. Pengenalan dan pengetahuan akan berbagai macam karakteristik suara instrumen musik menjadi pembimbing bagi pembuat film dan khususnya bagi pembuat film scoring.

Pada Program Studi D-3 Animasi, Fakultas Seni Media Rekam (FSMR), Institut Seni Indonesia (ISI) Yogyakarta, film scoring merupakan salah satu materi perkuliahan yang ada dalam mata kuliah Musik Ilustrasi 
dan Skoring. Dalam mata kuliah ini setiap mahasiswa dituntut untuk dpat membuat film scoring dalam film yang ditentukan oleh dosen. Seperti yang telah dipaparkan sebelumnya bahwa pembuatan film scoring membutuhkan pengetahuan dan pemahaman akan elemen musik, terutama pengetahuan akan berbagai macam instrumen musik berserta karakteristiknya, maka mahasiswa Prodi D-3 Animasi, FSMR, ISI Yogyakarta hendaknya memiliki pengetahuan dan pemahaman akan hal tersebut.

Dalam observasi awal yang dilakukan peneliti diketahui bahwa hampir sebagian besar mahasiswa yang mengambil mata kuliah musik ilustrasi memiliki sedikit pengetahuan dan pemahaman akan berbagai macam suara instrumen musik. Apabila hal ini dibiarkan, akan menjadi kendala dalam pembelajaran mata kuliah musik ilustrasi. Sebagai upaya untuk mengatasi permasalahan ini, peneliti menawarkan sebuah solusi, yaitu dengan membuat sampling berbagai macam suara instrumen musik sehingga diharapkan mahasiswa dapat mengenal dan memiliki pengetahuan akan berbagai macam suara instrumen musik beserta karakteristiknya sehingga dapat dijadikan sebagai pembimbing dalam memilih instrumen musik yang sesuai untuk pembuatan film scoring.

\section{SAMPLING}

Kata sampling sering digunakan dalam bidang statistik. Dalam statistik, sampling merupakan proses atau cara untuk mengambil sampel atau contoh untuk menduga sebuah keadaan (Sugiyono, 2013). Sama halnya dalam musik, sampling merupakan sebuah cara untuk mengambil sampel atau contoh musik untuk membuat sebuah musik yang baru (Wiséen \&
Herbertsson, 2015). Istilah sampling sering digunakan pada musik digital. Sampling musik sebenarnya sudah mulai ada pada sekitar tahun 1960-an.

Sampling musik menjadi sebuah materi yang menarik pada abad digital saat ini. Melalui sampling musik seseorang dapat menciptakan musik dengan kreativitas yang lebih luas. Dalam perkembangannya, sampling musik berkembang menjadi beberapa jenis, yaitu (1) Loops. Loops adalah bagian yang diulangulang diambil dari materi rekaman. Materi rekaman yang diulang-ulang dapat membentuk pola ostinato (pola motif atau frase musik yang diulang-ulang dengan suara yang sama atau dengan instrumen musik yang sama). Menurut Duffell (2005), loops merupakan bagian kecil dari sebuah rekaman, yang biasanya terdiri dari satu sampai dengan empat birama yang diulang-ulang secara terus menerus; (2) Musical Instrument. Musical instrument merupakan sampling musik yang dimainkan dengan suara instrumen musik dan biasanya, suara yang dimainkan adalah suara dari sebuah not, bukan sebuah motif ataupun frase seperti pada loops. Sampling musik ini banyak dibuat oleh perusahaan-perusahaan pembuat instrumen musik, dimainkan oleh pemusikpemusik professional dan direkam di studio musik professional; (3) Resampled layers of sounds. Resampled layers of sounds merupakan sampling musik untuk menghasilkan layer dari berbagai macam suara instrumen musik. Dalam proses pembuatannya, akan direkam berbagai macam instrumen musik yang berbeda-beda, kemudian diolah sehingga pada akhirnya suara instrumen musik yang berbeda-beda tersebut menjadi satu kesatuan suara; (4) Multi-samples. Multi-samples merupakan sampling musik untuk membentuk suara instrumen musik 
yang direkam menyerupai suara instrumen musik sesungguhnya dengan berbagai macam teknik sampling; (5) Recordings and popular examples. Recordings and popular examples merupakan sampling musik yang dibuat dari merekam berbagai macam musik popular. Pembuatan sampling musik jenis ini adalah dengan memotong beberapa fragmen musik dan diulang-ulang (loops) dengan menggunakan teknologi komputer; (6) Spoken Word. Spoken word merupakan sampling yang diambil dari film, televisi, atau media nonmusikal. Sampling ini berfungsi untuk menciptakan mood atau efek comic; dan (7) Unconventional sounds. Sampling musik ini merupakan sampling musik yang diambil dari suara-suara di alam sekitar dengan tujuan untuk menciptakan warna suara yang menarik dan berhubungan dengan membangkitkan emosi pendengar.

\section{INSTRUMEN MUSIK}

Instrumen musik atau alat musik merupakan alat yang digunakan untuk menghasilkan musik. Dalam perkembangannya, instrumen musik juga termasuk alat-alat yang dapat digunakan untuk menghasilkan bunyi atau suara. Berdasarkan sumber bunyinya, instrumen musik dapat dikelompokkan menjadi beberapa kelompok. Kelompok tersebut adalah (1) aerophone, merupakan instrumen musik yang sumber bunyinya berasal dari udara yang masuk melalui pipa melalui instrumen musik tersebut. Contoh instrumen musik aerophone adalah flute, oboe, klarinet, terompet, saksofon, dan lainnya; (2) membranophone merupakan instrumen musik yang sumber bunyinya berasal dari getaran membran. Contoh instrumen musik membranophone adalah timpani, conga, drum, bass drum, dan lainnya; (3) chordophone merupakan instrumen musik yang sumber bunyinya berasal dari senar atau tali senar instrumen musik tersebut. Contoh instrumen musik chordhophone adalah gitar, harpa, biola, cello, piano, dan lainnya; (4) ideophone merupakan instrumen musik yang sumber bunyinya berasal dariinstrumen musik itu sendiri dan dengan dipukul dengan menggunakan alat bantu. Contoh instrumen musik ideophone adalah timpani, drum, triangel, cymbal, dan lainnya; dan (5) electrophone merupakan instrumen musik yang sumber bunyinya berasal dari aliran listrik. Contoh instrumen musik electrophone adalah gitar elektrik, bass elektrik, keyboard, dan lainnya.

Selain dikelompokkan berdasarkan sumber bunyinya, instrumen musik dikelompokkan juga berdasarkan cara memainkannya, yaitu (1) instrumen musik petik, dimainkan dengan cara dipetik, contohnya gitar, harpa, siter dan lainnya; (2) instrumen musik gesek, dimainkan dengan cara digesek, contohnya biola, cello, contra bass, dan lainnya; (3) instrumen musik pukul, dimainkan dengan cara dipukul, contohny drum, xylophone, timpani, dan lainnya; (4) instrumen musik tiup, dimainkan dengan cara ditiup, contohnya flute, oboe, klarinet, trombone, tuba, dan lainnya; (5) instrumen musik getar, dimainkan dengan cara menggetarkan instrumen musik tersebut, contohnya marakas, bolero, dan lainnya; dan (6) instrumen musik keyboard, merupakan instrumen musik yang menggunakan bilah nada dalam susunan khusus dan dimainkan dengan ditekan dengan menggunakan jari, contohnya organ, piano, akordeon, dan lainnya.

Pengelompokan instrumen musik yang berikutnya adalah berdasarkan fungsi instrumen musik, yaitu (1) instrumen musik melodis, instrumen musik yang digunakan untuk menghasilkan melodi, contohnya 
biola, saxophone, flute, oboe, dan lainnya; (2) instrumen musik harmonis, instrumen musik yang fungsinya memainkan harmoni, contohnya gitar, keyboard, organ, piano, dan lainnya; dan (3) instrumen musik ritmis, instrumen musik yang berfungsi untuk memainkan ritme musik, contohnya drum, triangle, cymbal, grancasa, dan lainnya.

Dalam menciptakan musik, maka instrumen musik biasanya dimainkan bersama-sama dengan instrumen musik lainnya. Permainan musik bersama-sama ini dinamakan ansambel. Dalam permainan musik secara ansambel, maka instrumen musik yang digunakan biasanya adalah instrumen musik yang sejenis (instrumen musik yang memiliki kesamaan atau kimiripan). Pengelompokkan musik pada saat bermain ansambel akan dikelompokkan berdasarkan pengelompokkan instrumen musik dalam bentuk orkestra. Orkestra merupakan permainan musik bersama-sama dengan jumlah pemain yang banyak dan menggunakan instrumen musik yang bermacam-macam. Pengelompokan instrumen musik dalam orkestra terdiri dari: (1) strings, instrumen musik strings dalam orkestra terdiri dari biola (violin), biola alto (viola), cello (cellos), contra bass (double bass) dan harpa; (2) woodwinds, instrumen musik woodwinds dalam orkestra terdiri dari flute, oboe, klarinet, dan basson; (3) brass, instrumen musik brass dalam orkestra terdiri dari terompet, horn, trobone, dan tuba; (4) keyboard, instrumen musik keyboard dalam orkestra terdiri dari piano dan celesta; dan (5) percussions. Dalam orkestra, instrumen musik percussions dibagi menjadi dua, yaitu definite pitch (instrumen musik perkusi yang memiliki nada) dan undefinite pitch. Instrumen musik percussions dengan definite pitch terdiri dari timpani, marimba, xylophone, celesta, chimes, vibraphone, dan lainnya, sedangkan instrumen musik undefinite pitch contohnya bass drum, snare drum, triangel, maracas, tamborine, dan lainnya.

Pengelompokan instrumen musik dalam orkestra sering dijadikan dasar untuk mengelompokkan instrumen musik dalam sebuah ansambel. Pengelompokan instrumen musik dalam orkestra juga mengalami perkembangannya, namun bentuk dasar dari sebuah orkestra adalah terdiri dari kelompok instrumen musik strings, woodwinds, brass, keyboard, dan percussions.

\section{PENELITIAN TINDAKAN KELAS (PTK)}

Penelitian ini merupakan jenis penelitian tindakan kelas atau yang lebih dikenal dengan PTK (classroom action research). Pengertian kelas yang dimaksud dalam PTK bukanlah kelas dalam artian ruang kelas, melainkan tempat dimana terjadinya kegiatan belajar mengajar. PTK merupakan penelitian yang bertujuan untuk mengatasi permasalahan-permasalahan di dalam kelas, sehingga dapat meningkatkan kualitas pembelajaran agar dapat berlangsung secara efektif dan efisien (Sukanti, 2008).

PTK dipilih untuk digunakan sebagai sebuah cara untuk mendeskripsikan penggunaan sampling suara instrumen musik sebagai strategi pembelajaran mahasiswa Program Studi D-3 Animasi, Fakultas Seni Media Rekam, Instituts Seni Indonesia Yogyakarta dalam membuat film scoring pada mata kuliah Musik Ilustrasi dan Skoring.

Model PTK yang digunakan pada penelitian ini adalah model PTK yang dibuat oleh Kemmis dan Mc Taggart (Kemmis, S \& Mc Taggat, 1998). Pada umumnya, setiap siklus PTK terdiri dari empat tindakan, yaitu: 
(1) perencanaan; (2) tindakan; (3) pengamatan; dan (4) refleksi. PTK dapat diulang menjadi beberapa siklus, dan penentuan berapa siklus yang hendak digunakan berdasarkan hasil refleksi di setiap akhir siklus. Apabila di bagian refleksi didapatkan hasil yang sesuai dengan tujuan penggunaan PTK, siklus selanjutnya tidak digunakan. Pola setiap siklus selalu akan sama, hingga mendapatkan hasil yang diinginkan. Berikut empat tindakan yang ada pada setiap siklus PTK.

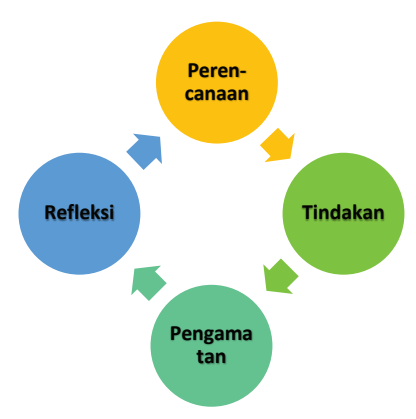

Gambar 1 Siklus PTK

Indikator keberhasilan PTK dalam penelitian ini didapat dari tingkat hasil belajar mahasiswa. Tingkatan keberhasilan pembelajaran dapat dibagi dalam beberapa tingkatan yaitu: (1) istimewa (maksimal), apabila seluruh materi pembelajaran dapat dikuasai oleh seluruh siswa; (2) baik sekali (optimal), apabila siswa dapat menguasai 85\% sampai dengan 94\% materi pembelajaran; (3) baik (minimal), apabila siswa dapat menguasai $75 \%$ sampai dengan $84 \%$ materi pembelajaran; dan (4) kurang, apabila siswa dapat menguasai kurang 75\% materi pembelajaran (Kunandar \& Si, 2010).

Tingkatan keberhasilan pembelajaran dapat dijadikan sebagai acuan dalam mengevaluasi proses pembelajaran. Untuk mengevaluasi pembelajaran, ada dua hal yang harus diperhatikan, yaitu: (1) Apabila $75 \%$ siswa mencapai tingkat keberhasilan minimal, optimal atau maksimal, maka proses pembelajaran dapat diteruskan ke materi selanjutnya; dan 2) Apabila 75\% siswa kurang mencapai keberhasilan minimal, optimal atau maksimal, maka harus diadakan perbaikan.

\section{PTK PRA SIKLUS}

Perolehan data mengenai kondisi awal (pra siklus) tentang hasil belajar mahasiswa pada pembelajaran Musik Ilustrasi dan Skoring menggunakan nilai dari tugas awal mahasiswa pada mata kuliah Musik Ilustrasi dan Skoring, yaitu membuat film scoring. Data hasil belajar pra tindakan pada mata kuliah tersebut dapat dilihat dalam tabel berikut ini.

Tabel 1 Hasil Belajar Prasiklus

\begin{tabular}{clcc}
\hline 1 & Amat Baik & 2 Mahasiswa & $12,5 \%$ \\
\hline 2 & Baik & 3 Mahasiswa & $18,75 \%$ \\
\hline 3 & Cukup & 1 Mahasiswa & $6,25 \%$ \\
\hline 4 & Kurang & 10 Mahasiswa & $62,5 \%$ \\
\hline Jumlah & & $\mathbf{1 6}$ Mahasiswa & $\mathbf{1 0 0 \%}$ \\
\hline
\end{tabular}

Dari data hasil penelitian prasiklus yang tergambar dalam tabel 1, diketahui bahwa terdapat permasalahan dalam pembelajaran Musik Ilustrasi dan Skoring, yakni rendahnya tingkat keberhasilan belajar mahasiswa dalam membuat film skoring. Berdasarkan tabel 1 terlihat bahwa mahasiswa yang mendapat nilai amat baik dan baik sebanyak 5 mahasiswa $(31,25 \%)$ dari 16 mahasiswa. Dapat dikatakan bahwa kurang dari 75\% (>75\%) mahasiswa mendapat nilai amat baik dan baik. Dari hasil ini dapat dikatakan bahwa terdapat permasalahan rendahnya hasil belajar mahasiswa dalam membuat film scoring. Dengan demikian, diperlukan tindakan untuk meningkatkan hasil belajar mahasiswa dalam mata kuliah Musik Ilustrasi dan Skoring, yaitu dengan menggunakan strategi pembelajaran sampling suara isntrumen musik. 
Proses pembuatan sampling suara instrumen musik dibuat dengan teknik rekaman digital. Proses rekaman digital meliputi proses perekaman suara menggunakan microphone condenser untuk menangkap sinyal suara dari instrumen musik. Suara yang ditangkap dari microphone condenser diteruskan ke dalam soundcard Yamaha AG-03 untuk diubah menjadi data digital yang selanjutnya diproses oleh komputer menggunakan software editing audio Apple Logic Pro X. Pada software editing audio, dilakukan proses noise remover untuk menghilangkan suara yang tidak diinginkan dan normalize untuk membuat suara cukup keras sampai pada level normal. Selanjutnya dilakukan mixdown atau export menjadi file mp3 256kbps 48kHz.

Instrumen yang direkam pertama adalah instrumen musik gesek (strings) seperti biola, biola alto, cello, dan contrabass. Perekaman biola menggunakan microphone condenser yang dihubungkan ke soundcard untuk direkam ke dalam komputer menggunakan software Apple Logic Pro $X$. Hasil rekaman kemudian diolah dengan noise reduction untuk menghilangkan suara yang tidak diinginkan dan normalize untuk meratakan kekerasan suara.

Instrumen musik yang direkam berikut adalah instrumen musik tiup kayu (woodwinds) seperti flute, oboe, clarinet, dan bassoon. Proses perekaman dalam instrumen tiup kayu dilakukan seperti proses perekaman instrumen gesek, yaitu menggunakan microphone condenser yang dihubungkan ke soundcard kemudian direkam oleh komputer menggunakan software Apple Logic Pro $X$. Hasil rekaman kemudian diolah dengan noise reduction untuk menghilangkan suara yang tidak diinginkan dan normalize untuk meratakan kekerasan suara.
Instrumen musik yang direkam berikutnya adalah instrumen musik tiup logam (brass) seperti terompet, french horn, trombobe, dan tuba. Proses perekaman yang dilakukan sama seperti yang dilakukan pada instrumen gesek dan tiup kayu. Setelah instrumen musik piano, gitar akuistik, dan instrumen musik perkusi seperti marimba, xylophone, wood block, cymbal, triangel, grand casa, dan castanyet. Proses perekaman pun dilakukan seperti dalam proses perekaman instrumen musik sebelumnya.

\section{PTK SIKLUS I}

Pelaksanaan siklus I dilaksanakan pembelajaran dilakukan dengan langkahlangkah sebagai berikut. (1) Perencanaan. Perencanaan siklus I difokuskan untuk mengatasi masalah yang ditemukan pada observasi awal dan prasiklus, yaitu rendahnya hasil belajar mahasiswa. Berdasarkan hal tersebut, dibuat perencanaan yang terdiri dari: mengamati pelaksanaan proses pembelajaran oleh dosen mengenai kemampuan mahasiswa dalam belajar serta kemampuan memahami materi perkuliahan, membuat perencanaan pembelajaran, menentukan materi perkuliahan, dan membuat lembar tes; (2) Tindakan. Peneliti melaksanakan pembelajaran Musik Ilustrasi dan Skoring dengan menggunakan sampling suara instrumen musik untuk membuat film scoring. Pada tahap pelaksanaan tindakan, pembelajaran di kelas dipusatkan pada substansi yang menjadi masalah pokok untuk meningkatkan hasil belajar mahasiswa. Setiap akhir tindakan dilaksanakan tes untuk mengetahui hasil belajar mahasiswa; (3) Pengamatan dan Hasil Tindakan. Pengamatan berjalan bersamaan dengan pengamatan tindakan yang sedang berjalan. Pada tahap ini 
peneliti melakukan pengamatan dan mencatat semua hal yang diperlukan. Pengumpulan data dilakukan dengan menggunakan format observasi atau penilaian yang telah disusun sebelumnya; dan (4) Reflkesi. Refleksi yang dilakukan berdasarkan hasil belajar mahasiswa dalam membuat film scoring. Berdasarkan belajar yang didapat pada siklus I, terdapat $7(43,75 \%)$ mahasiswa yang mendapat nilai amat baik dan baik. Hasil pada siklus I adalah belum tercapainya target $75 \%$ dari mahasiswa mendapat nilai amat baik dan baik, sehingga dibutuhkan siklus selanjutnya (siklus II).

\section{Tabel 2 Hasil Belajar Mahasiswa Siklus I}

\begin{tabular}{|c|c|c|c|}
\hline No & $\begin{array}{c}\text { Hasil } \\
\text { Belajar } \\
\text { Mahasiswa }\end{array}$ & Jumlah & Persentase \\
\hline 1 & Amat Baik & 5 mahasiswa & $31,25 \%$ \\
\hline 2 & Baik & 2 mahasiswa & $12,5 \%$ \\
\hline 3 & Cukup & 1 mahasiswa & $6,25 \%$ \\
\hline Kurang & 4 & 8 mahasiswa & $50 \%$ \\
\hline Jumlah & & 16 mahasiswa & $100 \%$ \\
\hline
\end{tabular}

\section{PTK SIKLUS II}

Dalam pelaksanaan siklus II, perencanaan pembelajaran dilakukan dengan langkahlangkah sebagai berikut: (1) Perencanaan. Perencanaan proses pembelajaran pada siklus II ditekankan pada peningkatan hasil belajar mahasiswa dalam membuat film scoring. Pada siklus ini, mahasiswa diberi latihan untuk membuat film scoring. Setelah mahasiswa membuat film skoring, akan dievaluasi kembali hasil belajar mahasiswa; (2) Tindakan. Pada tahap pelaksanaan tindakan, peneliti melaksanakan pembelajaran Musik Ilustrasi dan Skoring dengan menggunakan sampling suara instrumen musik untuk membuat film scoring. Pada tahap pelaksanaan tindakan, pembelajaran di kelas dipusatkan pada substansi yang menjadi masalah pokok untuk meningkatkan hasil belajar mahasiswa; (3) Pengamatan dan Hasil Tindakan. Seperti pada siklus I, pengamatan dilakukan bersamaan dengan tindakan yang sedang berjalan. Pada tahap ini peneliti melakukan pengamatan dan mencatat semua hal yang diperlukan; dan (4) Refleksi. Pada siklus II mahasiswa yang mendapat nilai amat baik dan baik sebanyak 11 mahassiswa $(81,25 \%)$. Target pelaksanaan PTK pada siklus II dalam penelitian ini telah tercapai. Namun, peneliti melanjutkan kembali PTK dalam penelitian ini ke siklus III untuk memastikan bahwa strategi pembelajaran dengan menggunakan sampling suara instrumen musik merupakan strategi yang tepat untuk meningkatkan hasil belajar mahasiswa dalam membuat film scoring.

Tabel 3 Hasil Belajar Mahasiswa Siklus II

\begin{tabular}{clcc}
\hline No & $\begin{array}{c}\text { Hasil Belajar } \\
\text { Mahasiswa }\end{array}$ & Jumlah & Persentase \\
\hline 1 & Amat Baik & 9 Mahasiswa & $56,25 \%$ \\
2 & Baik & 4 Mahasiswa & $25 \%$ \\
3 & Cukup & 2 Mahasiswa & $12,5 \%$ \\
4 & Kurang & 1 Mahasiswa & $6,25 \%$ \\
\hline & Jumlah & $\mathbf{1 6}$ Mahasiswa & $\mathbf{1 0 0 \%}$ \\
\hline
\end{tabular}

\section{PTK SIKLUS III}

Dalampelaksanaan siklus III, perencanaan pembelajaran dilakukan dengan langkahlangkah sebagai berikut: (1) Perencanaan. Pada siklus III, perencanaan proses pembelajaran ditekankan pada peningkatan hasil belajar mahasiswa serta mengetahui apakah strategi pembelajaran dengan menggunakan sampling suara instrumen musik merupakan strategi pembelajaran yang tepat dalam membaut film scoring; (2) Tindakan. Tindakan yang dilakukan pada siklus III adalah lebih banyak memberikan bimbingan terhadap latihan pembuatan film skoring agar mahasiswa lebih paham terhadap 
pemilihan instrumen musik yang sesuai dengan karakter dan mood film; (3) Pengamatan Dan Hasil Tindakan. Seperti dalam siklus-siklus sebelumnya, pengamatan dilakukan bersamaan dengan tindakan yang sedang berjalan; dan (4) Refleksi. Hasil belajar pada siklus III menunjukan bahwa 15 (93,75\%) mahasiswa mendapat nilai amat baik dan baik. Hasil ini menunjukkan bahwa strategi pembelajaran menggunakan sampling suara instrumen musik terbukti dapat meningkatkan hasil belajar mahasiswa dalam membuat film scoring.

Tabel 4 Hasil Belajar Mahasiswa Siklus III

\begin{tabular}{clcc}
\hline No & $\begin{array}{c}\text { Hasil Belajar } \\
\text { Mahasiswa }\end{array}$ & Jumlah & Persentase \\
\hline 1 & Amat Baik & 13 Mahasiswa & $81,25 \%$ \\
2 & Baik & 2 Mahasiswa & $12,5 \%$ \\
3 & Cukup & 1 Mahasiswa & $6,25 \%$ \\
4 & Kurang & 0 Mahasiswa & $0 \%$ \\
\hline & Jumlah & 16 Mahasiswa & $\mathbf{1 0 0 \%}$ \\
\hline
\end{tabular}

\section{PEMBAHASAN}

Dari hasil belajar setiap siklus PTK yang telah dipaparkan, dapat diketahui bahwa penggunaan sampling suara instrumen musik pada perkuliahan Musik Ilustrasi dan Skoring di Prodi D-3 Animasi, FSMR, ISI Yogyakarta dapat meningkatkan hasil belajar mahasiswa. Hasil ini juga sekaligus menyatakan bahwa sampling suara instrumen musik merupakan strategi pembelajaran yang tepat untuk mengajarkan film scoring.

Keberhasilan pembelajaran dengan menggunakan sampling suara instrumen musik dapat dilihat dari pencapaian mahasiswa untuk memperoleh nilai amat baik dan baik. Dari proses prasiklus hingga siklus III diketahui bahwa terdapat peningkatan jumlah mahasiswa yang mendapat nilai amat baik dan baik. Pembelajaran dapat dikatakan berhasil jika
75\% dari jumlah seluruh mahasiswa mencapai nilai baik dan amat baik. Pada akhir siklus III diketahui bahwa sebanyak 93,75\% mahasiswa mendapat nilai amat baik dan baik. Persentase 93,75\% merupakan persentase lebih dari persentase tingkat keberhasilan mahasiswa, yaitu $75 \%(93,75 \%>75 \%)$.

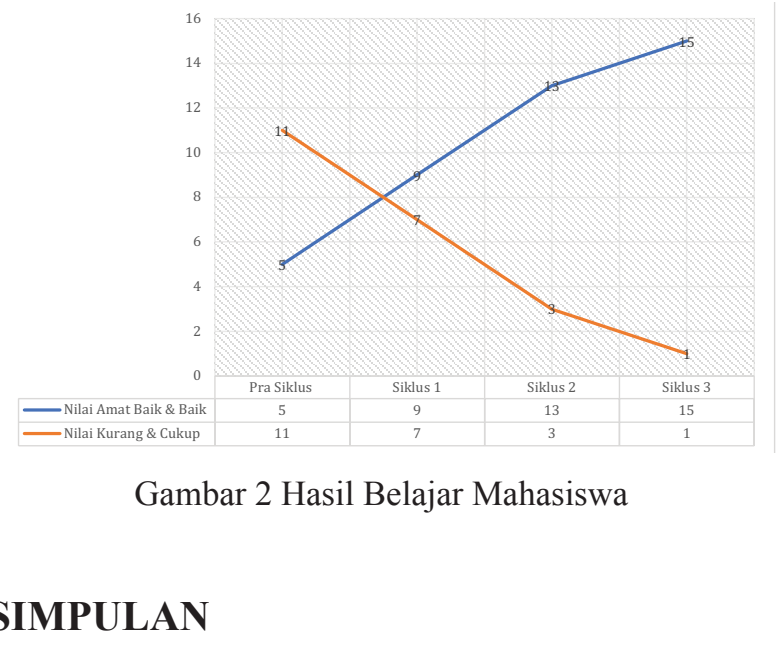

Hasil penelitian ini menunjukkan bahwa strategi belajar menggunakan sampling suara instrumen musik dalam pembuatan film scoring terbukti dapat meningkatkan hasil belajar mahasiswa. Penggunaan sampling suara instrumen musik dalam pembuatan film scoring juga tidak saja meningkatkan hasil belajar mahasiswa, tetapi dapat juga meningkatkan pengetahun dan pemahaman mahasiswa terhadap berbagai macam suara instrumen musik yang digunakan sebagai rujukan dalam memilih instrumen musik yang tepat pada pembuatan film scoring sehingga dapat menciptakan emosi penonton film.

\section{KEPUSTAKAAN}

Cohen, A. J. (2001). "Music as a Source of Emotion in Film". Music and Emotion: Theory and Research, Vol, No: 249-272.

Douek, J. (2013). "Music and Emotion-a composer's perspective". Frontiers in Systems Neuroscience, 7, 82: hlm. 
Duffell, D. (2005). Making Music with Samples: Tips, Techniques \& 600+ Ready-to-use Samples. Kota penerbit: Hal Leonard Corporation.

Indovoiceover. (2016). Music dalam Film: Elemen Penting Industri Film. lengkapi

Kemmis, S \& Mc Taggat, C. (1998). The Action Reseacrh Planner. kota: Deakin University Press.

Kunandar, S. P., \& Si, M. (2010). Guru Profesional Implementasi Kurikulum Satuan Pendidikan (KTSP) dan Sukses dalam Sertifikasi Guru. Jakarta: Penerbit PT Raja Grafindo Persada.

Kurniawan, T. U. (2016). "Perwujudan Naskah Drama Anusapati Karya SH Mintardja dalam Pementasan Teater." Journal of Urban Society's Arts, 3(2), 73-81.

Mark, B. (2003). "Film Music and Film Genre". Doctoral Dissertation, University of Stirling.

Nalan, A. S. (2017). "Pertunjukan Musik Teatrikal 'IBU' Produksi Teater Koma." Resital: Jurnal Seni Pertunjukan, 18(1), 13-26.

Sugiyono, M. P. K. (2013). Kualitatif dan Kombinasi (Mixed Methods). Bandung: Alfabeta.

Sukanti, S. (2008). "Meningkatkan Kompetensi Guru Melalui Guru Melalui Pelaksanaan Penelitian Tindakan Kelas". Jurnal Pendidikan Akuntansi Indonesia, 6(1).: hlm.

Wiséen, M., \& Herbertsson, J. (2015). The legality of music sampling in Sweden: Complicated issues demand complicated measures. Kota: Penerbit

Wu, B., Horner, A., \& Lee, C. (2014). Musical timbre and emotion: The identification of salient timbral features in sustained musical instrument tones equalized in attack time and spectral centroid. In ICMC. Jika jurnal vol, no, hlm. 